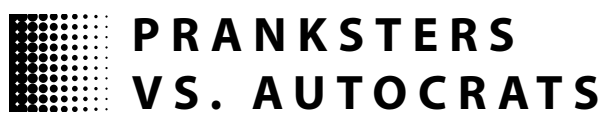




\section{McCourtney Institute for Democracy}

The Pennsylvania State University's McCourtney Institute for Democracy (http://democracyinstitute.la.psu.edu) was founded in 2012 as an interdisciplinary center for research, teaching, and outreach on democracy. The institute coordinates innovative programs and projects in collaboration with the Center for American Political Responsiveness and the Center for Democratic Deliberation.

\section{Laurence and Lynne Brown Democracy Medal}

The Laurence and Lynne Brown Democracy Medal recognizes outstanding individuals, groups, and organizations that produce exceptional innovations to further democracy in the United States or around the world. In even numbered years, the medal spotlights practical innovations, such as new institutions, laws, technologies, or movements that advance the cause of democracy. Awards given in odd numbered years highlight advances in democratic theory that enrich philosophical conceptions of democracy or empirical models of democratic behavior, institutions, or systems. 


\title{
PRANKSTERS VS. AUTOCRATS
}

\section{WHY DILEMMA ACTIONS ADVANCE NONVIOLENT ACTIVISM}

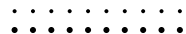 \\ 0

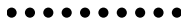 \\ $\bullet \bullet \bullet \bullet \bullet \bullet \bullet \bullet \bullet \bullet$ \\ 부부불 \\ pereecere \\ $1+t+t+t+4$ \\ $+++++++$ \\ SRDJA POPOVIC \\ WITH \\ SOPHIA A. MCCLENNEN
}

CORNELL SELECTS

an imprint of

CORNELL UNIVERSITY PRESS

Ithaca and London 
Cornell Selects, an imprint of Cornell University Press, provides a forum for advancing provocative ideas and fresh viewpoints through outstanding digital and print publications. Longer than an article and shorter than a book, titles published under this imprint explore a diverse range of topics in a clear and concise format-one designed to appeal to any reader. Cornell Selects publications continue the press's long tradition of supporting high quality scholarship and sharing it with the wider community, promoting a culture of broad inquiry that is a vital aspect of the mission of Cornell University.

Open access edition funded by the McCourtney Institute for Democracy at Pennsylvania State University

Copyright $\odot 2020$ by Cornell University

The text of this book is licensed under a Creative Commons Attribution-NonCommercial-NoDerivatives 4.0 International License: https://creativecommons.org/licenses/by-nc-nd/4.0/. To use this book, or parts of this book, in any way not covered by the license, please contact Cornell University Press, Sage House, 512 East State Street, Ithaca, New York 14850. Visit our website at cornellpress.cornell.edu.

First published 2020 by Cornell University Press

Library of Congress Cataloging-in-Publication Data

Library of Congress Control Number: 2020941265 